FEATURE

\title{
Chicago's 132-year effort to provide safe drinking water
}

Kenneth R. Olson and Lois Wright Morton

M ore than 180 years ago, the city of Chicago, Illinois, established on lacustrine and alluvial soils near the Chicago River along the shores of Lake Michigan, had an abundance of water upon which its industries thrived and population grew. However, this exuberant growth quickly overwhelmed water resources that served transportation and commerce, industrial and residential waste disposal, and public drinking water supply. The original $0.9 \times 1.2 \mathrm{~m}(3 \times 4 \mathrm{ft})$ intake pipe that reached $183 \mathrm{~m}(600 \mathrm{ft})$ into Lake Michigan and connected to a suction well was soon inadequate to assure safe drinking water as high levels of raw sewage were dumped into the lake (Ward 1994). The reversal of the Chicago River, construction of the Chicago Sanitary and Shipping Canal (figure 1), and investments in water treatment systems over the last century have improved Chicago's management of raw and treated sewage and debris, attempts to eliminate typhoid germs, and capacity to monitor other bacteria within Chicago area river systems and nearshore waters (Sible et al. 2015; Olson and Morton 2016). By the 1960s, as Chicago's population and industries continued to expand, the Tunnel and Reservoir Plan (TARP, also known as the Deep Tunnel Project) was created to intercept stormwater runoff and raw sewage overflow as well as control flooding throughout the city. Today, the Chicago Area Waterway System (CAWS) is a network of modified rivers, underground tunnels, and canals (Sinha et al. 2013), which are used for navigation and shipping, residential and industrial wastewater management, aesthetics, and recreation.

Kenneth R. Olson is professor emeritus of soil science in the College of Agricultural, Consumer, and Environmental Sciences, University of Illinois, Urbana, Illinois, and Lois Wright Morton is professor of sociology in the College of Agriculture and Life Sciences, lowa State University, Ames, lowa.

\section{Figure 1}

A tugboat pushes a barge on the Chicago Sanitary and Ship Canal past a coal-fired electric power plant.

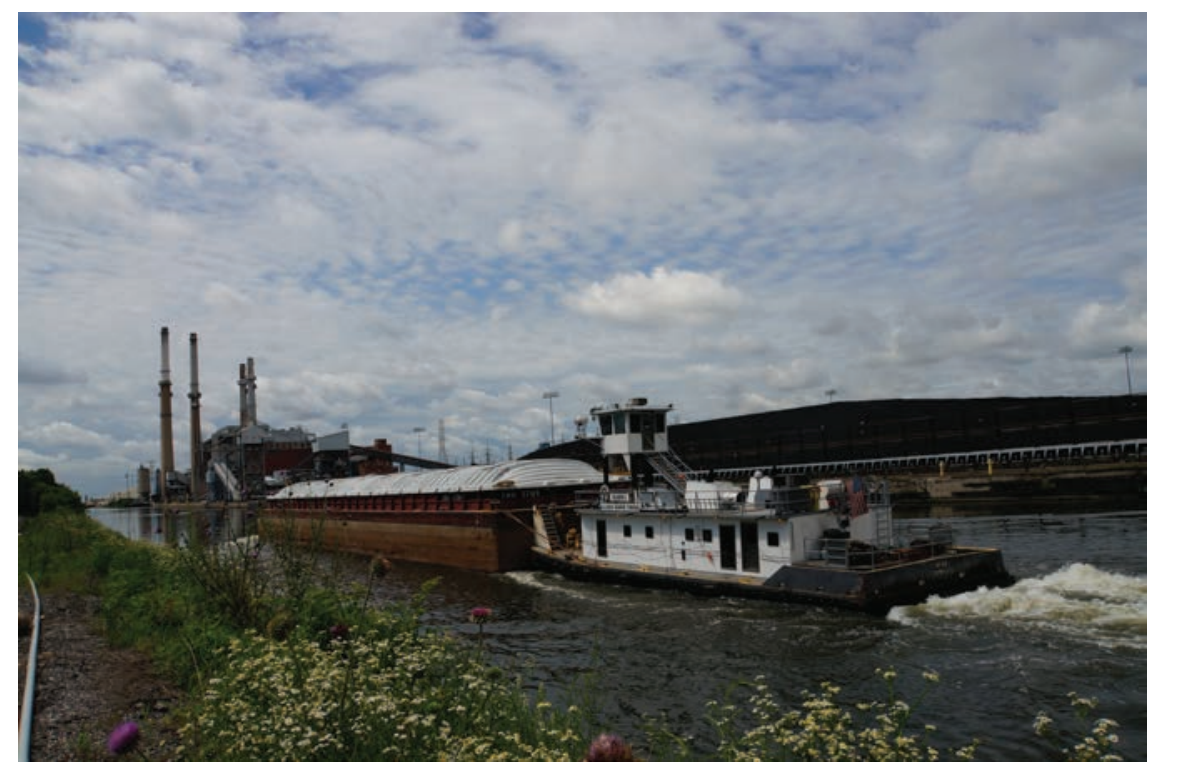

\section{THE ILLINOIS AND MICHIGAN CANAL CONNECTS CHICAGO TO THE ILLINOIS RIVER}

The canals and rivers of the 1800 s were the primary transportation routes for passengers and commercial trade across the United States. The construction of the Illinois and Michigan Canal (1836 to 1848) (figure 2) accelerated the growth of Chicago at the intersection of eastern markets, midwestern meat production and packing, and the shipping of raw and manufactured products. The Illinois and Michigan Canal began at Lake Michigan and the mouth of the Chicago River (figure 3) and ran south to connect to the Des Plaines and Illinois rivers (not shown). The canal was dug through glacial lake deposits and Milford soils. About $19 \mathrm{~km}$ (12 mi) west of Lake Michigan, it crossed the continental drainage divide that separates Lake Michigan watershed from the Des Plaines watershed.The canal had to be cut through this 3.7 to $7.3 \mathrm{~m}$ (12 to $24 \mathrm{ft}$ ) high ridge (Valparaiso moraine) of glacial outwash and glacial lake sediments (Selma and Oakville soils). Once the continental drainage divide was crossed, the canal was dug in alluvium and outwash deposits that overlie dolomite bedrock on bottomlands and terraces (Romeo and Joliet soils) of the Des Plaines River valley. The Illinois and Michigan Canal (figure 2) was almost $32 \mathrm{~km}$ (20 mi) long, $18 \mathrm{~m}$ (60 ft) wide,

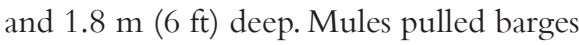
filled with cargo along towpaths that were constructed beside the canal (Putnam 1918). The canal had 4 aqueducts and 17 locks to enable navigation of the $43 \mathrm{~m}$ $(140 \mathrm{ft})$ drop from Lake Michigan to the Illinois River (Smith 1900).

The canal was a thriving passenger and shipping route from 1848 to 1852 . However, passenger service ended in 1853 when the Chicago, Rock Island, and Pacific Railroad, built adjacent to the canal, opened.The canal stayed in use until 1893, but 1882 was the peak shipping year for the canal (Edwards and Harris 1998). The Illinois and Michigan Canal was partially replaced in 1900 by the Chicago Sanitary and Ship Canal, which was wider and deeper (figure 1), and later by the Illinois Waterway in 1933. 


\section{CONTAMINATION OF CHICAGO'S DRINKING WATER SUPPLY}

The Chicago and Calumet rivers (figure 3 ) and connecting canals were used in the 1800s for navigation and waste disposal for stockyards, meat packing plants, and other industries; they were used similarly by city residents. The Great Chicago Fire of 1871 destroyed stockyards, wooden industrial buildings, and residential houses in much of Chicago. The growth of the city was not slowed, and rebuilding occurred rapidly along the Illinois and Michigan Canal, the Chicago River, and the shores of Lake Michigan. With increasing population, the Illinois and Michigan Canal (figure 2) became badly polluted by untreated sewage and industrial debris and waste. Following the Great Fire, the canal was dredged to increase the speed of the water flow and move sewage more quickly into Lake Michigan. A large storm in 1885 dropped high levels of precipitation in a short period of time on the city and resulted in runoff that washed untreated sewage and debris far out into the lake. This put Chicago's drinking water supply at risk since the city water intakes were located $3.2 \mathrm{~km}(2 \mathrm{mi})$ offshore. Although typhoid and cholera were risks, no epidemics occurred. However, this was a wakeup call, and in 1889 the Illinois legislature created the Chicago Sanitary District (currently the Metropolitan Water Reclamation District of Greater Chicago).

The Chicago Sanitary District designed a plan to build a network of channels and canals that would reverse the flow of the Chicago and Calumet rivers (figure 3) away from Lake Michigan and redirect wastewater and contaminated runoff downstream (figure 4) into the Illinois River where pollutants could be diluted and treated naturally as waters flowed to the Mississippi River.The US Army Corps of Engineers (USACE) reversed the direction of a portion of the Chicago River in 1892, and Chicago's sewage began to flow into the Illinois and Michigan Canal southward instead of into Lake Michigan. However, this was a temporary fix; and the complete reversal of the Chicago River's flow was not accomplished until the Sanitary and Ship Canal was opened in 1900 .

\section{Figure 2}

This quiet preserved section of the Illinois and Michigan Canal at Lockport, Illinois, was once a busy waterway filled with boats. The Illinois and Michigan Canal, built in 1848, connected the Chicago River to the Illinois River through 17 locks and 4 aqueducts.

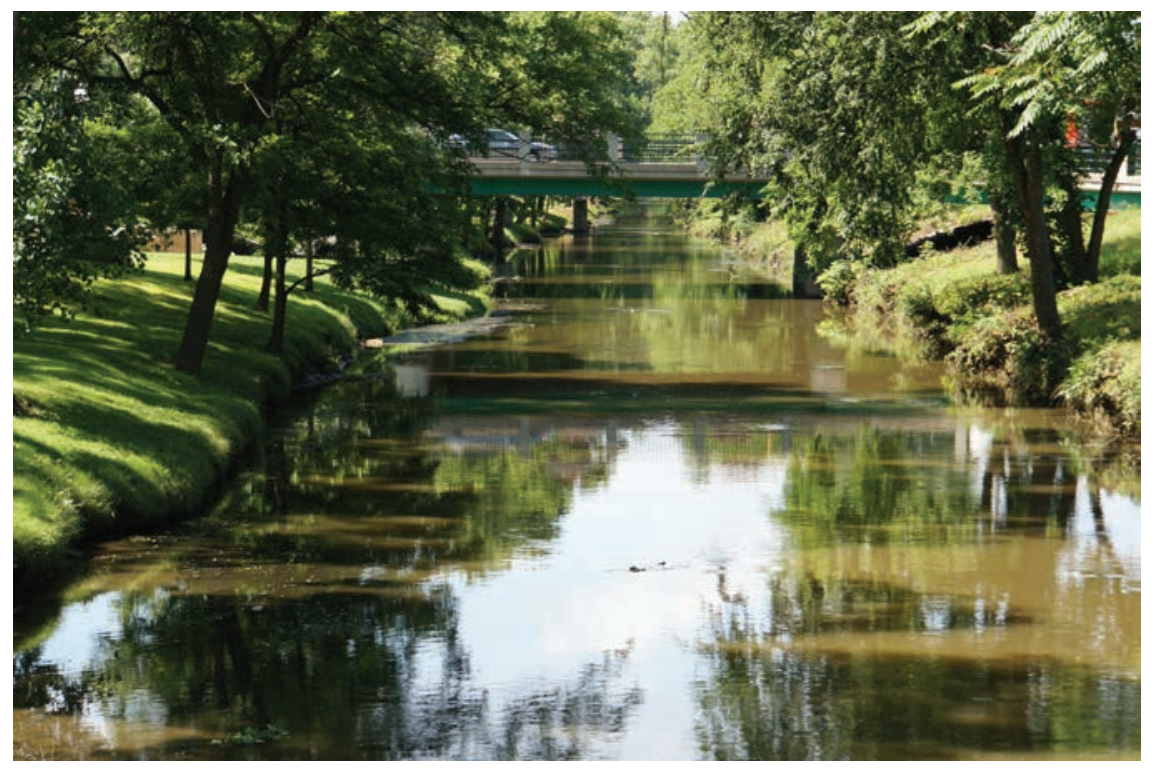

\section{REVERSAL OF THE CHICAGO RIVER AND CONSTRUCTION OF THE CHICAGO SANITARY AND SHIP CANAL}

The permanent reversal of the Chicago and Calumet rivers with the construction of the Chicago Sanitary and Ship Canal was an immense municipal public works achievement that became internationally known as one of the seven wonders of American engineering (Ward 1994). It provided training for a generation of engineers, many of whom later went on to design and construct the Panama Canal and the Headwaters Diversion levee and drainage system south of Cape Girardeau, Missouri (Olson et al. 2016). More than 9.2 million $\mathrm{m}^{3}$ (12 million $\left.\mathrm{yd}^{3}\right)$ of rock were blasted and hauled away. Additionally, over 22.9 million $\mathrm{m}^{3}\left(30\right.$ million $\left.\mathrm{yd}^{3}\right)$ of earth were moved (Ward 1994). The end result was a $45 \mathrm{~km}$ (28 mi) long, $61 \mathrm{~m} \mathrm{(202}$ $\mathrm{ft})$ wide, and $7.3 \mathrm{~m}(24 \mathrm{ft})$ deep canal that diverted Chicago's industrial and sanitary waste away from Lake Michigan into the Des Plaines and Illinois rivers (figure 4). It also made Chicago a key midwestern port with shipping connections between the Great Lakes Waterway and the Mississippi River system to the Gulf of Mexico (figure 5) (Olson and Morton 2016).
The Chicago Sanitary and Ship Canal linked the south branch of the Chicago River to the Des Plaines River at Lockport and was opened on January 2, 1900. The flow of the water was permanently reversed (figure 4) by January 17. Later, the Chicago Sanitary and Ship Canal was extended to Joliet (1903 to 1907) in order to replace the smaller Illinois and Michigan Canal and handle larger barges and more shipping traffic. A few years later, the North Shore Channel (1910) and the CalumetSaganashkee (Calumet-Sag or Cal-Sag) Canal (1922) were built (figures 4 and 6).

\section{MOVEMENT OF WATER AND POLLUTANTS ACROSS THE TRANSCONTINENTAL DIVIDE AND THE CHICAGO AREA WATERWAY SYSTEM}

Chicago wastewater flowed into Lake Michigan before 1900 via the Calumet and Chicago rivers (figure 3 ). Prior to the construction of the Chicago Sanitary and Ship Canal, the shallower and narrower Illinois and Michigan Canal connected the waterways for navigable shipping over the Chicago Portage (Olson and Morton 2016). With the construction of the Chicago Sanitary and Ship Canal, wastewater flowed toward the Des Plaines River (figure 4), into the Illinois River, and then 


\section{Figure 3}

This map shows the water flow of the Chicago and Calumet rivers into Lake Michigan prior to 1900 . The continental drainage divide separates Lake Michigan from the Des Plaines and Illinois rivers that flow south into the Mississippi River.

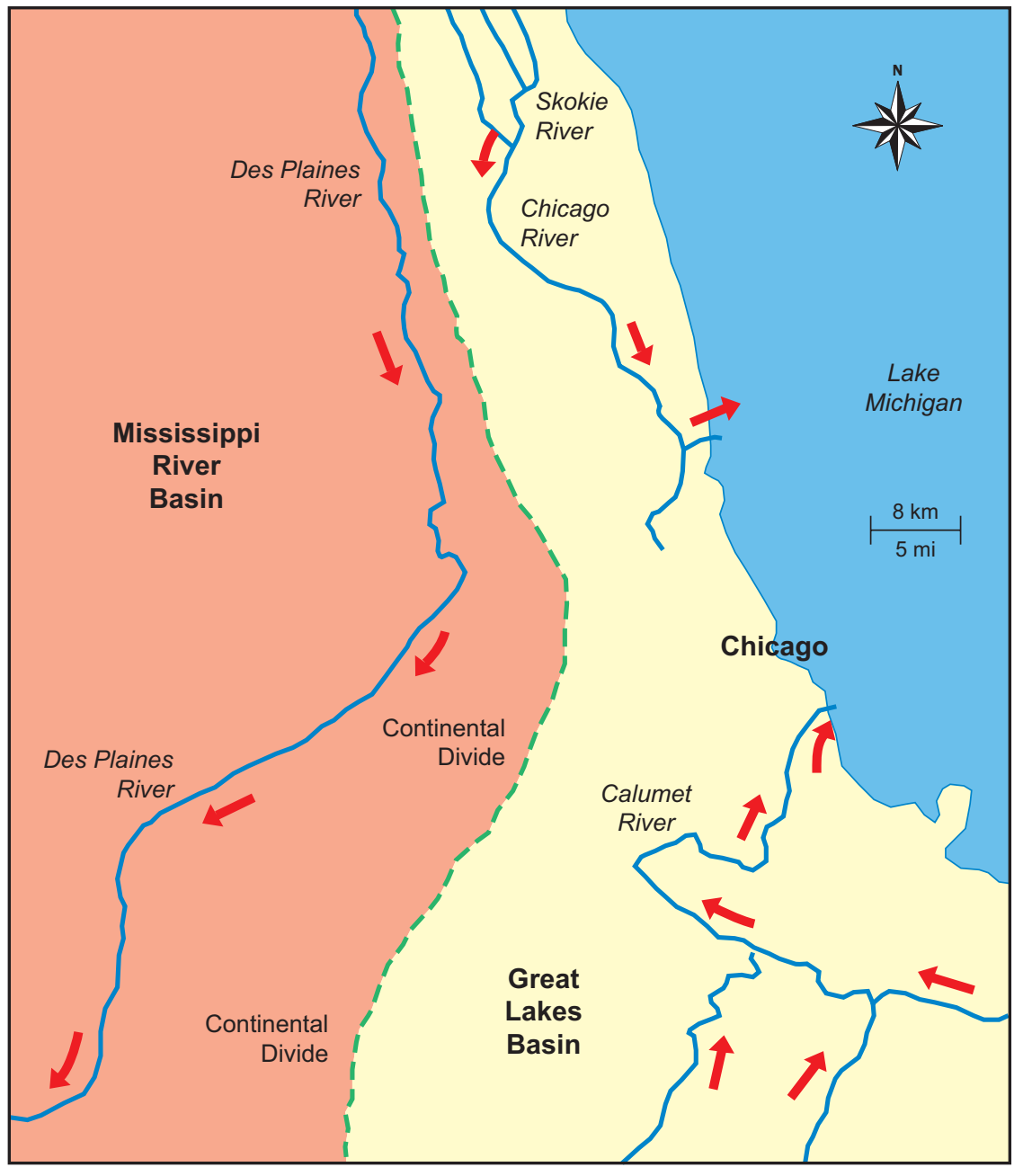

into the Mississippi River. Note that figure 3 does not show the Illinois and Michigan Canal built in 1848 that crossed the continental divide that separates the drainage of the Great Lakes basin and the Mississippi River basin.

Today the Chicago River flows away from Lake Michigan to the west where it merges with the North Shore Channel and into the Chicago Sanitary and Ship Canal. The CAWS has eight reaches consisting of canals, underground tunnels, and rivers that have been modified. It also includes four water treatment and reclamation plants on the banks of the waterway (Sinha et al. 2013). This channelized water system throughout the Chicago area has no floodplain and no natural water fil- tering capacity. Urbanization of Chicago has changed the hydrology of this water network, of which more than $70 \%$ is treated wastewater from reclamation plants (Sinha et al. 2013). Impervious surfaces in the core urban area of Chicago (Cook County) exceed $30 \%$ of land cover. This diminishes groundwater infiltration and accelerates the rate and volume of runoff that the Metropolitan Water Reclamation District must manage.

\section{CHICAGO SANITARY AND SHIP CANAL WATER DIVERSION}

The Chicago Sanitary and Ship Canal was intended to redirect water from Lake Michigan and discharge it into the Mississippi River watershed (figure 4). A specific quantity of water was authorized to be diverted away from Lake Michigan under the US Rivers and Harbors Acts (Olson and Morton 2016). The reversed flow and increased volume of water has effectively flushed untreated sewage away from Lake Michigan. However, water limits have not been honored or sufficiently regulated over the years, and the canal has impacted water levels in the US-Canadian managed Great Lakes and St. Lawrence River. Litigation began as early as 1907 when a court suit, Sanitary District of Chicago vs. United States, was forwarded to the Supreme Court. Downstream states sided with the Chicago Sanitary District; a few years later the issue continued to be litigated as Wisconsin vs. Illinois. Canal management was turned over to the USACE in 1930 , and the flow of water into the canal was reduced while retaining the important navigation function. Court decisions have pushed the sanitary district to invest in treating the city's raw sewage. Today, an international treaty involving Canada and the governors of the Great Lakes states jointly monitors and regulates water diversions from the Great Lakes system through the International Joint Commission.

\section{THE ILLINOIS WATERWAY SYSTEM}

The Chicago Sanitary and Shipping Canal and the Illinois River are part of the $14,000 \mathrm{~km} \mathrm{(9,000} \mathrm{mi)} \mathrm{Mississippi}$ River system that is navigable because of extensive lock and dam engineering. The Illinois Waterway runs from the Chicago and Calumet rivers in Chicago to Grafton, Illinois (figure 5), where the Illinois River flows into the Mississippi River (Olson and Morton 2016) connecting the Great Lakes to the Gulf of Mexico. The waterway drops from $173 \mathrm{~m}(578 \mathrm{ft})$ above sea level at Lake Michigan to $126 \mathrm{~m}$ (419 ft) at the mouth of the Illinois River as it flows southwest into the Mississippi River. Eight locks (figure 5) control water flow along the entire $538 \mathrm{~km}$ (336 mi) system that has a $2.7 \mathrm{~m}$ (9 ft) deep navigation channel. Two additional locks and dams on the Mississippi River north of St. Louis, Missouri, make navigation possible from Chicago to St. Louis and points further south (Olson and Morton 2014). The construction of the Chicago Sanitary and Ship 


\section{Figure 4}

This 2015 map shows the direction of the water in the Chicago canals after the Chicago and Calumet rivers were reversed to carry wastewater away from Lake Michigan into the Chicago Sanitary and Ship Canal and south into the Illinois Waterway and the Mississippi River.

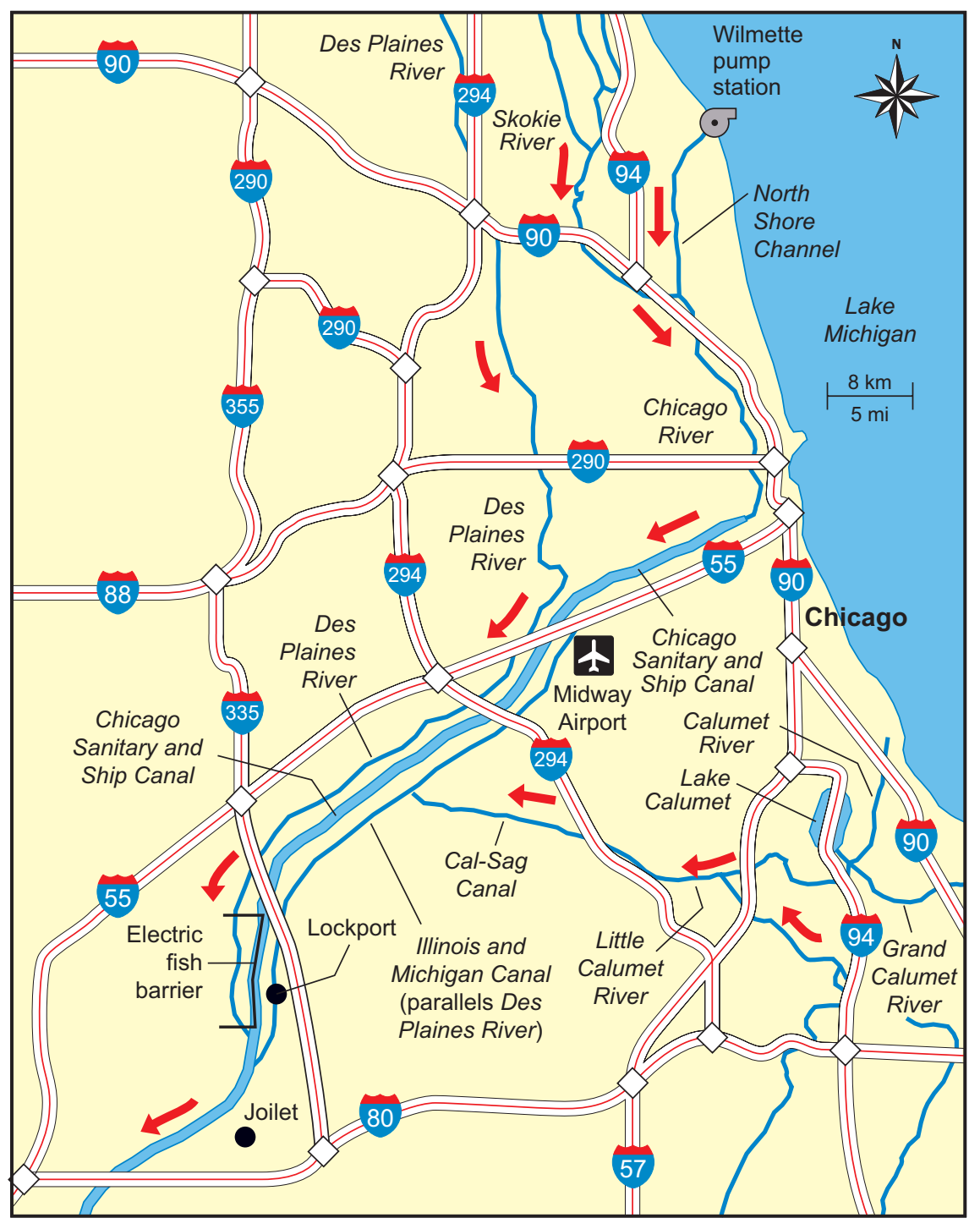

Canal and the reversing of the Chicago River to flow out of rather than into Lake Michigan made this waterway a major route for shipping goods to be transported to international markets between the port of Chicago and the port of New Orleans, Louisiana, at the mouth of the Mississippi River (Weeks 2008).

\section{MUNICIPAL WASTEWATER AND INDUSTRIAL SEWAGE SLUDGE}

Not only do the locks on the Chicago area canals enable ships to move through the waterway, they also separate and control
Another challenge the Metropolitan Water Reclamation District must manage is the sewage sludge that is removed during the treatment of Chicago's residential and industrial wastewaters. The industrial waste and sewage sludge contains heavy metals, such as cadmium (Cd). The Calumet and Chicago sludge from wastewater treatment plants have been shipped on barges for over 40 years to Knox County to reclaim strip mine soils with the hope of returning the land to agricultural production (Henesly et al. 1982). However, there has been concern that the heavy metals would contaminate the food supply if reclaimed strip mined areas are put back in agricultural production. As a result, the Knox County strip mines have become waste disposal sites rather than corn (Zea mays L.) and soybean fields (Glycine max [L.] Merr.). The sludge is also used to reclaim made land along the rivers.

\section{CALUMET-SAG CANAL AND THE TUNNEL AND RESERVOIR PLAN}

Lake Michigan is not only connected to the Des Plaines and Illinois rivers by the Chicago River but also by the CalumetSag Canal (figures 4 and 6). This canal, dug between 1911 and 1922, is $26 \mathrm{~km}(16 \mathrm{mi})$ long and starts at the Little Calumet River, cuts through the Valparaiso moraine (or continental drainage divide), and merges with the Chicago Sanitary and Ship Canal north of Lockport. Prior to 2006, the Calumet-Sag Canal was used by barge traffic in an active industrial zone. After 2006, it became a primary conduit for wastewater from southern Cook County and the Chicago area TARP.The TARP is intended to address two water problems: (1) expand the sewer system capacity so that raw sewage is not released into the Chicago River during high rain events, and (2) manage flooding within the metropolitan Chicago area (Ward 1994; Schmidt et al. 2009).

Essentially, the TARP is a river constructed under the city consisting of 176 $\mathrm{km}(110 \mathrm{mi})$ of tunnels and reservoirs that capture and hold stormwater and raw sewage until it can be treated and released into the Calumet and Des Plaines rivers. The first phase consists of a system of tunnels ranging from 2.7 to $10 \mathrm{~m}$ (9 to $33 \mathrm{ft}$ ) in 
diameter and dug up to $107 \mathrm{~m}(350 \mathrm{ft})$ deep that are designed to intercept 8.7 billion L (2.3 billion gal) of stormwater and sewage overflow and direct it into multibillion liter (billion gallon) underground storage reservoirs (Ward 1994). This phase, built between 1975 and 2006 at a cost of more than US $\$ 3$ billion, has captured and treated more than a trillion gallons of wastewater since 1985 (Lydersen 2011). The second phase, managed by the USACE as a flood control project, is estimated to be completed in 2029. The TARP will have a 66 billion L (17.5 billion gal) capacity of sewage and stormwater storage once completed.

Three storage reservoirs in the system are large rock (primarily dolomite) quarries with considerable capacity: Gloria Alitto Majewski Reservoir (1,327 million L [350 million gal]); Thornton Composite (29.9 billion L [7.9 billion gal]); and McCook Reservoir (37.9 billion L [10 billion gal]). The tunnels are more than three stories high and were built using state-of-the-art, laser-guided tunnel boring machines that weigh 907 t (2 million lb) (Ward 1994). Computer controlled steel disks within the cutter head break up the rock and deposit excavated materials on conveyors that can automatically move about $6,880 \mathrm{~m}^{3}$ $\left(9,000 \mathrm{yd}^{3}\right)$ daily (Ward 1994).

\section{BIGHEAD AND SILVER CARP AND THE MANMADE CHICAGO CANALS}

The extensive tunnel and canal system through Chicago has been highly effective in reducing urban flooding and controlling release of wastewater that could pollute Lake Michigan. However, the Chicago canal and waterway system connecting the Illinois Waterway and Mississippi River to Lake Michigan presents a new threat to the lake: Asian carp. The silver carp (Hypophthalmichthys molitrix), also known as flying carp (Olson and Morton 2016), were first introduced into Arkansas catfish farms in 1970 to control algae. Silver carp have since escaped into the Mississippi River system and migrated upstream into tributaries. These large carp jump above the water to make their way upstream (figure 7) and can grow to $23 \mathrm{~kg}$

\section{Figure 5}

The Illinois Waterway, which encompasses the Illinois River and Chicago canals has eight locks and dams that allow barges to navigate between the Great Lakes and the Mississippi River.

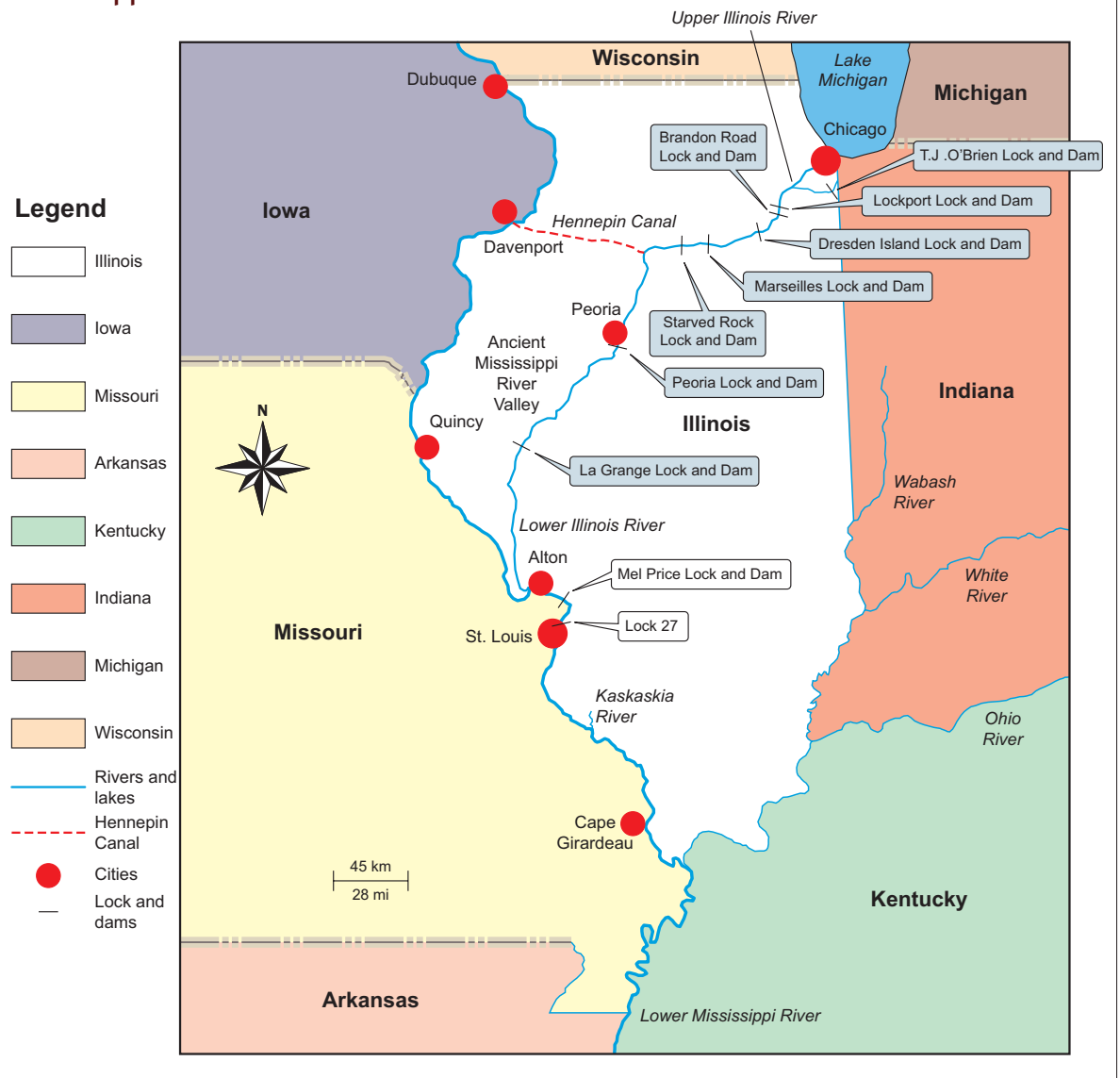

\section{Figure 6}

The Calumet-Sag Canal drains treated wastewater from the south side of Chicago and suburbs into the Chicago Sanitary and Ship Canal.

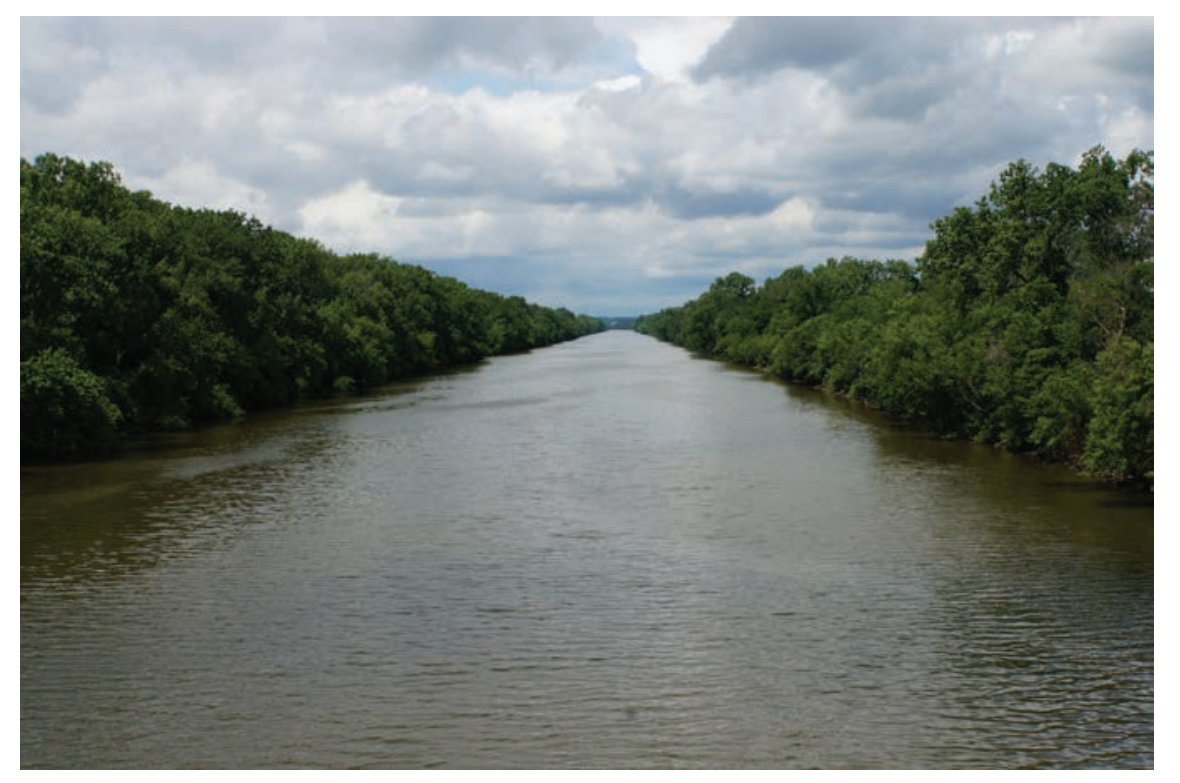




\section{Figure 7}

Flying Asian carp jump out of the water to travel upstream on the Illinois River at the Marseilles Lock and Dam.

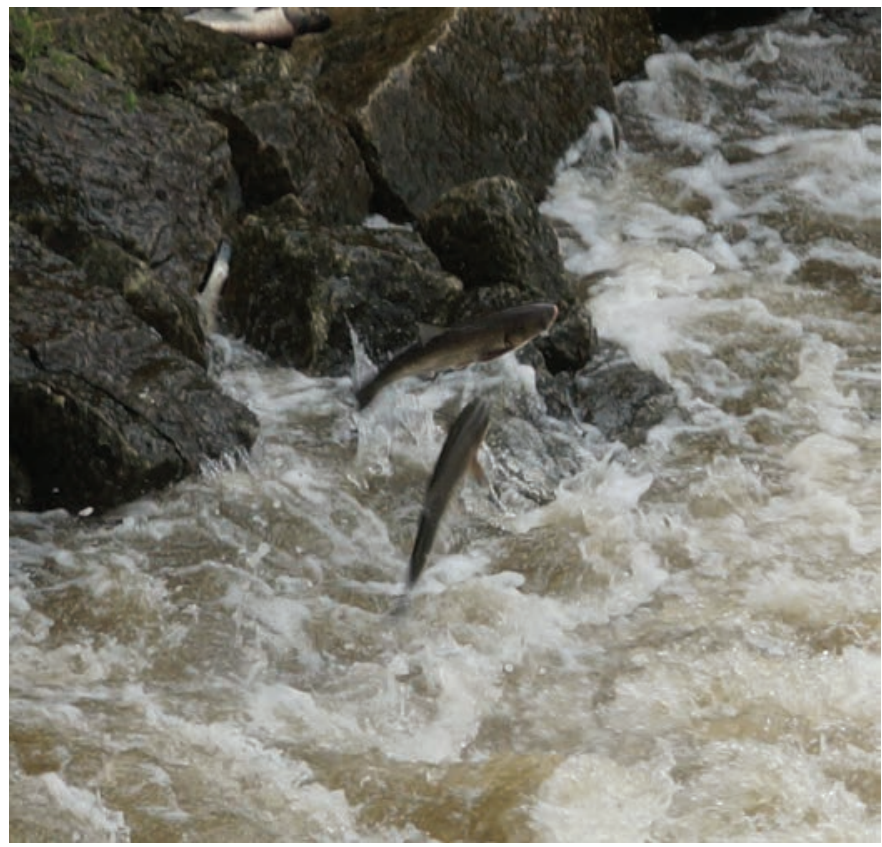

(50 lb) or more. As an invasive species, the Asian carp threaten native river and lake species of filter feeding fish by voraciously consuming the bottom of the food chain.

There are several kinds of carp that have spread (or are spreading) around North America, and the two that have received the most attention at present are the silver carp and bighead carp (Hypophthalmichthys nobilis) (personal communication with Cory David Suski, Department of Natural Resources and Environmental Sciences, University of Illinois). There are other carp (black carp [Mylopharyngodon piceus] and grass carp [Ctenopharyngodon idella]) that are less prominent, but silver and bighead are the biggest concern at present as there are 18 different paths by which they can pass from the Mississippi River basin into the Great Lakes (Olson and Morton 2016). Most of these paths only have water at certain times of the year, but the Chicago Waterway is the most prominent concern because the extensive network of canals and tunnels have water year round. The carp do not displace native fish but outcompete them for food, and several fish species (particularly filter feeding fish) have experienced reduced environmental

\section{Figure 8}

from entering Lake Michigan (figure 8). The Chicago Sanitary and Ship Canal was temporarily closed on December 2, 2009, after the USACE disclosed on November 20, 2009, that Asian carp DNA was found above the electric barrier (figure 8). The US Environmental Protection Agency and the Illinois Department of Natural Resources applied rotenone in the water to destroy any fish that had escaped north of the Lockport electric barrier. Inspection of the fish kill and two months of intensive commercial fishing and electrofishing did not find any Asian carp. Alarmed by the potential disaster of Asian carp in Lake Michigan, Michigan State Attorney General Mike Cox filed a lawsuit on December 21, 2009, with the US Supreme Court seeking the immediate closure of the Chicago Sanitary and Ship Canal. Codefendants named in the lawsuit were the State of Illinois and the USACE, who constructed and manage the canal. The main arguments presented against closing the canal were economic with estimates of more than US $\$ 1.5$ billion a year in lost revenues from millions of tons of grain, coal, iron $(\mathrm{Fe})$ ore, and other barge shipments if they were not able to use the waterway, as well as job losses. Rebuttal from the Great Lake states of Michigan, Minnesota, and Ohio

An electric fish barrier on the Chicago Sanitary and Ship Canal prevents invasive species in the Illinois Waterway from entering Lake Michigan.

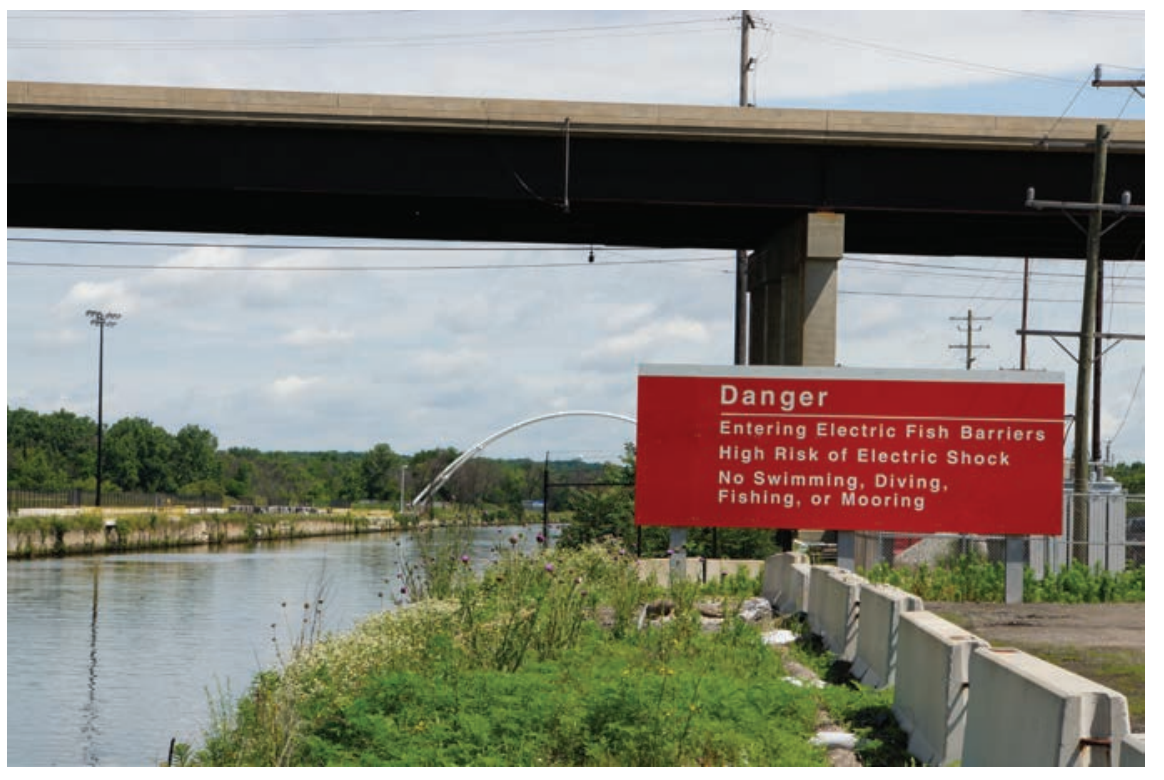


claimed that commercial and sport fishery and tourism on the Great Lakes were at risk, an annual economic loss valued at US $\$ 7$ billion. The US Supreme Court rejected the request for a preliminary injunction to close the canal on January 19,2010, and the ruling was upheld by the United States Court of Appeals in 2011.

\section{SUMMARY AND CONCLUSIONS}

In 1885, Chicago's Lake Michigan drinking water supply was threatened by runoff water carrying waste, refuse, and pollutants. For the last 132 years, Chicago has worked to protect their drinking water by digging canals through the continental drainage divide and reversing the flow of the Chicago River. The drinking water intakes were later extended further out into Lake Michigan to reduce the chances of contamination and a future epidemic. Reversing the flow of the Chicago River by building the Sanitary and Ship Canal was one of the most enduring and successful efforts to flush sewage away from Lake Michigan and protect Chicago's drinking water supply and provide a $2.7 \mathrm{~m}$ (9 ft) navigation channel between Lake Michigan and the Mississippi River via the Illinois Waterway (Olson and Morton 2016).

The linkage of the Great Lakes to the Mississippi River resulted in waste being disposed of in the tributaries of the Mississippi River to avoid contaminating Chicago's drinking water. The decision to transfer refuse and raw sewage into the Mississippi River drainage system was not a popular one in downstate Illinois. The issue was partially addressed by the creation of wastewater treatment plants in the Chicago area. However, these wastewater treatment plants generated tons of sludge that have since been stored in Knox County strip-mined lands.

Population growth, urban land use, increases in impervious surfaces, and changes in land cover affect the rate and volume of rainwater that flows into Chicago sewer pipes (Wilson and Weng 2010). Thus, concerns about water pollution continue to be a challenge during flooding and extreme rain events. The completion of the second phase of the TARP project in 2029 is expected to reduce urban flooding and improve the water quality of the Illinois Waterway and Lake Michigan. While the canals and reversed flow of Chicago River and the TARP project protect Lake Michigan and Chicago's drinking water supply, a new problem has emerged more than 100 years later. Connecting the Great Lakes and Mississippi drainage systems had the unintended consequence of providing a pathway for two invasive fish species to potentially migrate from the Mississippi River into the Great Lakes. Electric barriers temporarily prevent Asian carp from entering the Great Lakes, but it is not certain whether they are a long-term solution.

Reversing the canal and river flows again and discharging treated wastewater back into Lake Michigan is no longer a possibility since the lake is the primary viable source of Chicago drinking water. The growth of Chicago's suburban areas has been restricted for years since the quality and amount of groundwater are insufficient to support additional intensive development; without access to the drinking water supply in Lake Michigan they could not further develop. If Lake Michigan were to become contaminated again, the entire population of the Chicago area would be at risk as it was in 1885. Maintaining the Chicago River reversal and continuing wastewater treatment and disposal of sludge on previously strip-mined lands appears to be the only viable option in the twenty-first century.

\section{ACKNOWLEDGEMENTS}

Published with funding support from the Director of the Illinois Office of Research, College of Agricultural, Consumer, and Environmental Science, University of Illinois, Urbana, Illinois. Additional funding was provided by the USDA National Institute of Food and Agriculture (NIFA) Integrated Water Program agreement 2008-51130-19526, Heartland Regional Water Coordination Initiative, and the Iowa Agriculture and Home Economics Experiment Station, College of Agriculture and Life Sciences at Iowa State University, Ames, Iowa.

\section{REFERENCES}

Edwards, R., and E. Harris. 1998. Prairie Passage:The Illinois and Michigan Canal Corridor. Urbana, IL: University of Illinois Press.

Henesly, T.D., K.E. Redborg, E.L. Ziegler, and I.H. Rose-Innes. 1982. Effects of chemical and physi- cal changes in strip-mined spoil amended with sewage sludge on the uptake of minerals by plants. In Land Reclamation and Biomass Production with Municipal Waste Water and Sludge, eds. W.E. Sopper, E.M. Seaker, and R.K. Bastian, pp. 339352. University Park, PA: The Pennsylvania State University Press.

Lydersen, K. 2011. Pressure to improve water quality in Chicago River. New York Times, May 20, p. A19B. Olson, K.R., and L.W. Morton. 2014. Runaway barges damage Marseilles lock and dam during 2013 flood on the Illinois River. Journal of Soil and Water Conservation 69(4):104A-109A, doi:10.2489/jswc.69.4.104A.

Olson, K.R., and L.W. Morton. 2016. Managing the Mississippi and Ohio River Landscapes. Ankeny, IA: Soil and Water Conservation Society.

Olson, K.R., L.W. Morton, and D. Speidel. 2016. Missouri Ozark Plateau Headwaters Diversion engineering feat. Journal of Soil and Water Conservation 71(1):13A-19A, doi:10.2489/ jswc.71.1.13A.

Putnam, J.W. 1918. The Illinois and Michigan Canal: A study in Economic History. Chicago, IL: University of Chicago Press.

Schmidt, A., K. Fitzpatrick, J. Sobanski, R. Layon, and M. Garcia. 2009. Hydrologic and Hydraulic Modeling of the Tunnel and Reservoir Plan System in Northeastern Illinois. Universities Council on Water Resources Conference Report. Carbondale, IL: Southern Illinois University.

Sible, E., A. Cooper, K. Malki, K. Bruder, T. Hatzopoulos, S.C. Watkins, and C. Putonti. 2015. Assessment of microbial populations within Chicago area nearshore waters and interfaces with river systems. Data in Brief 5:305-308.

Sinha, S., S. Liu, and M.H. Garcia. 2013. A threedimension water quality model of Chicago Area Waterway System (CAWS). Environmental Modeling and Assessment 18:567-592.

Smith, A.E. 1900. The Chicago Drainage Canal. The Outlook 64.9.

Ward, J. 1994. 100 years of public works: 1894-1994. American City and County (Sept). Kansas City, MO: American Public Works Association.

Weeks, J.A. 2008. The Bridges and Structures of the Illinois River. Highways, Byways, and Bridge Photography. First ed., July 2008. www. johnweeks.com/river_illinois/index.html.

Wilson, C., and Q. Weng. 2010. Assessing surface water quality and its relation with urban land cover changes in the Lake Calumet Area, Greater Chicago. Environmental Management 45:1096-1111. 